\title{
El Martín Fierro Como Obra de Arte Literaria
}

Toda literatura tiene necesidad de una base estética que la levante a un nivel superior a la realidad y aun a la vida misma. Lo artístico, lo estético de una obra literaria necesita integrarse totalmente con la materia tratada, con el tema, pero al mismo tiempo - y quizás paradójicamentetiene que valer por su propia cuenta y ha de ser sentido como algo independiente. De modo que, por ejemplo, El doctor Jivago, llevado a la pantalla, no es lo mismo que la novela, y pese a su admirable adaptación cinematográfica, no puede juzgarse con el mismo criterio artístico que aplicamos a la obra original. En un caso, rige el criterio verbal; en el otro, el visual. Quiero decir con sólo este ejemplo (podría agregar muchos más), que el elemento puramente verbal parece no recibir la debida atención, o cuando menos se lo acepta como un ingrediente tan obvio y neutro que queda sumergido por otros de mayor importancia.

Por honda y significativa que sea la temática de Martín Fierro, como obra de literatura el valor tiene que residir en el lenguaje, en las palabras mismas como vehículo para expresar ideas y narrar sucesos. Observación ésta demasiado simplista e ingenua quizás, pero conviene insistir en ella porque en el caso de Martín Fierro lo social, lo cultural, lo político y aun lo antropológico se elevan a tal grado en la evaluación del poema que pueden llegar a echar sombras sobre su arte poético. Martín Fierro no puede ser simplemente la totalidad de las impresiones gauchescas y nacionales que se recogen a través de la obra; ni puede ser tampoco un compendio de ideologías o una sarta de protestas contra un gobierno insensible. El poema es todo esto, pero es también mucho más que esto, o cuando menos posee esas cualidades amén de una fuerza verbal o pujanza elocutiva que encauza el interés y valores estéticos de la obra. En verdad, la pregunta básica debe ser: ¿Cuáles son los elementos

${ }^{1}$ He utilizado en este estudio la edición de Cultural Argentina, 1961. Todas las citas se refieren a esta edición. 
del poema que más nos conmueven? ¿Qué es lo que nos hace sentir con tanta emoción el destino de Fierro, de Cruz, y de los hijos? Es más que el hilo narrativo; es el lenguaje mismo, que es una feliz fusión de gran expresividad verbal y espontánea naturalidad. $Y$ esto en gran medida es la norma estética que envuelve la composición de Martín Fierro y lo que nos mantiene en vilo. Hernández ha sabido fundir la vivacidad y la precisión narrativas con un idioma peculiarmente regional pero a la vez de resonancia nacional. La cualidad afectiva del poema se relaciona directamente con este conjunto de modalidades verbales. Más que nada, reaccionamos ante una creación lingüistica capaz de hacernos sentir hondamente las peripecias de los protagonistas a pesar de lo vulgar y prosaico de las voces y los giros. En fin, la lengua vernácula trasciende los límites impuestos por su propio carácter y se convierte en una vía eficaz de expresión de sentimientos y actos a que todos respondemos.

Lo que quiero decir, en resumen, es que Martin Fierro se lee con delectación y fervor emocional no tanto porque nos arrastre el hilo narrativo, ni siquiera porque nos fascine el tema de la persecución y opresión del gaucho y su lucha por la libertad personal. Se lee con placer - sea en voz alta o voz baja - porque cada estrofa llega impregnada de un no sé qué de atracción verbal, invitándonos a gustar del poema a medida que va desarrollảndose. No es menester aguardar hasta el final de la obra para saborear sus méritos. La impresión total que recibimos de una pieza literaria es mucho más generosa que la que sacamos de ella durante el proceso mismo de la lectura. Solemos exclamar, por ejemplo, al terminar una obra tediosa pero de fuerte sentido social: "¡Ah, qué buen simbolismo implícito en la figura del héroe!"; o "¡Qué duro es el ataque que hace el autor a los dictadores!"; o "QQué bien representa el protagonista las ideas progresistas del novelista!" Todo esto, tan favorable, aunque la obra falle como literatura. En Martín Fierro, los valores están plenamente a la vista a cada paso, precisamente porque el concepto artístico que rige la obra depende de la rica potencia del lenguaje mismo. No es que yo desatienda los juicios sobre el valor temático, sobre la conciencia nacional, sobre la psicología que entraña la obra. Pero estimo más las evaluaciones que expresan el constante, uniforme y omnipresente interés que se desprende de cada páigina del poema.

La violencia, la sangre, la exacta y horripilante descripción de actos de crueldad forman también parte imprescindible del relato y de la concepción estética de Martín Fierno. El gaucho vive con la sangre y de ella es preciso escribir; de otra manera, el poema falsificaría la vida gauchesca y perdería su elemento de completa naturalidad que es uno de sus triunfos. Pero el verdadero interés en esta brutalidad está en que detrás de la 
violencia hay sufrimiento, pena emocional, y una suerte de razonamiento e inteligencia que por un lado rechaza la crueldad y por otro la acepta como condición impuesta sobre la vida pampeana. Si comparamos la violencia en Martín Fierro con la expuesta en las mediocres novelas de Eduardo Gutiérrez (1851-1889), vemos la distinción de conceptos artísticos. Gutiérrez describe la violencia sin más ni más, en una forma desnuda y absoluta, y por esta razón carece de valor literario; en Martín Fierro la violencia se ve como algo trágico, ya que existe conflicto humano. Sea la lucha a muerte con el negro o la pelea con el indio, Hernández siempre muestra la violencia menos como puro acto físico que como condición poco deseada a la cual el gaucho tiene que resignarse.

Uno de los elementos que engendra este interés es lo que podemos llamar la alternancia de diferentes modos de expresión verbal, vale decir distintas perspectivas para hacer hincapié en la idea que se quiere expresar o en la acción descrita. En cierto nivel es obvio el interés que despierta la relación en primera persona de Martín Fierro, de Cruz, del hijo mayor, del moreno, y de otros; pero esto ya se ha comentado mucho y no es preciso repetirlo. Lo que es quizá más interesante y lo que presta interés a todo el relato es la alternancia dentro de la misma estrofa o en una serie de tres o cuatro estrofas. Examinaremos este recurso artístico en los siguientes versos, que bien pueden ser representativos de otros muchos. Habla Fierro:
Ninguno me hable de penas, porque yo penando vivo, y naides se muestre altivo aunque en el estribo esté, que suele quedarse a pie el gaucho más alvertido. ${ }^{2}$

Vemos que el primer verso -_- "Ninguno me hable de penas"-- se dirige en general a todos los hombres, con una oración exhortativa para mayor fuerza. En el segundo verso - "porque yo penando vivo"- el empleo de la primera persona hace más intensa la congoja de Fierro. En el tercero y cuarto versos, se recurre también al subjuntivo exhortativo, formando con la voz "naides" un paralelo estructural con "ninguno" de la primera línea. En los dos últimos versos, se hace referencia específica al gaucho, reforzando así las palabras expresadas arriba. Se echan de ver también otras maneras de enfocar la oración para crear interés y avivar

2 Martin Fierro, op. cit., p. 137. 
la narración. Frecuente es el empleo de la exclamación, como en " $i A h$, pulpero habilidoso!"; $;$ y aun de la exclamación prolongada como en "iAh tiempos - si era un orgullo / ver jinetiar un paisano!"^o en "iQuién sabe cómo estaría / del susto que había llevao!"'s

Otra estrofa nos aclarará más este recurso de alternancia de diferentes modos de expresión:

Yo llevé un moro de número.

¡Sobresaliente el matucho!

Con él gané en Ayacucho

más plata que agua bendita:

siempre el gaucho necesita

un pingo pa fiarle un pucho. ${ }^{6}$

En estos versos se puede seguir el desarrollo del pensamiento mediante la variedad de perspectiva verbal: 1) la afirmación directa en primera persona del primer verso, seguida de la exclamación que casi personifica las excelentes cualidades del caballo. El irónico empleo de la palabra "matucho", que generalmente se refiere a un caballo con ulceraciones, aquí revela gran admiración por el animal, 2) en los versos tercero y cuatro una íntima asociación entre jinete y animal, hecha más viva por la imagen del "agua bendita". 3) y a continuación, en los dos últimos versos, un sucinto comentario genetal sobre la condición del gaucho que vincula más la suerte de Fierro a la de todos los hombres de la pampa.

Otra técnica de alternancia es la de citar directamente las palabras de los que intervienen en la acción, como el jefe militar en esta estrofa:
En la lista de la tarde
el jefe nos cantó el punto,
diciendo: "Quinientos juntos
llevará el que se resierte;
lo haremos pitar del juerte;
más bien dése por dijunto".?

O cuando el segundo hijo de Martín Fierro narra cómo el juez manipula su destino:

\footnotetext{
3 Ibid., p. 171

- Ibid, p. 141.

5 Ibid., p. 242.

- Ibid., p. 151.

7 Ibid., p. 153.
} 
El juez vino sin tardanza

cuanto falleció la vieja.

"De los bienes que te deja",

Me dijo, "yo he de cuidar;

es un rodeo regular

y dos majadas de ovejas". ${ }^{8}$

A veces el narrador cede su lugar a otro personaje, dejando que éste, a través de una serie de estrofas, discurra largamente para acrecentar el interés. De manera que las palabras directas del alcalde, que conoce mejor que nadie la malicia de Vizcacha, corrobora el retrato de éste expuesto antes por Fierro y al mismo tiempo produce otro centro de interés estético. Dice el alcalde:

"De mozo fue muy jinete, no lo bajaba un bagual;

pa ensillar un animal

sin necesitar de otro,

se encerraba en el corral

y allí galopiaba el potro". ${ }^{9}$

Sigue el alcalde en otra estrofa:
"Se llevaba mal con todos;
era su costumbre vieja
el mesturar las ovejas,
pues al hacer el aparte
sacaba la mejor parte
y después venía con quejas". ${ }^{10}$

A continuación se encuentran ocho estrofas más que redondean la relación hecha por el alcalde.

Frecuentes en Martín Fierro son los comentarios medio filosóficos, proverbiales o aforísticos hechos por casi todos los personajes principales del poema. Estas observaciones, tan aptas y sentenciosas, son el meollo mismo de la vida gauchesca y prestan un aire de cordura pueblerina a la obra. No importa que en verdad al gaucho medio no se le conceda esta agilidad mental para expresar sus ideas con tanta frescura y precisión.

\footnotetext{
8 Ibid., p. 409.

- Ibid., p. 434.

10 Ibid., p. 434.
} 
Dado el juego literario en que todos participamos, se acepta esta transferencia linguística del poeta a los personajes que éste ha creado. En efecto, toda obra escrita en primera persona forzosamente se vale de esta estratagema. $\mathrm{Y}$ en parte el interés estético de Martín Fierro está en esta aparente incompatibilidad entre la crudeza vulgar de los incidentes narrados y el gran conocimiento del espíritu humano tan bien expresado en estas frases. Lo acertado, lo preciso, y lo agudo de los comentarios producen en el lector un efecto de hondas verdades salidas de boca de los sabios. La inteligencia y perspicacia que yacen al fondo del habla nos sorprenden y alientan nuestro interés. Todo el poema está concebido casi como una oposición entre la violencia y los aforismos morales y filosóficos, como en estos ejemplos:

Aquí no valen dotores:

sólo vale la esperiencia. ${ }^{11}$

Tiene la suerte del güey

¿y dónde irá el güey que no ara ?12

Vaca que cambia querencia

se atrasa en la parición. ${ }^{13}$

El que gana su comida

bueno es que en silencio coma. ${ }^{14}$

Hagámosle cara fiera

a los males, compañero,

porque el zorro más matrero

suele caír como un chorlito. ${ }^{15}$

Todo poema es imagen o sugerencia; es difícil concebirlo en otra forma. Metáfora, símil, analogía, y toda clase de tropos, a la vez que da realce a la expresión artística, nos hacen sentir con mayor sensibilidad que estamos frente a una obra literaria. Hay imágenes de puro adorno, de puro oropel, frias y estáticas; hay otras más funcionales que trasladan el pensamiento de un nivel a otros; y otras aún en que la transferencia es tan estrambótica y exagerada que se desvanecen los puntos de contacto

\footnotetext{
11 Ibid, p. 222.

12 Ibid., p. 215.

13 Ibid., p. 421

14 Ibid., p. 425.

15 Ibid., p. 236.
} 
y se crea una poesía hermética y surrealista. En Martin Fierro la imagen está tan estrechamente ligada a la narración y al alma del poema como para formar una sola entidad. La imagen corre, fluye y se funde con las otras palabras en una perfecta integración de formas de expresión. Y la fuente de la imagen es la fuente de la vida pampera — los animales, la naturaleza, las tareas diarias, las necesidades físicas. ${ }^{16}$ Lo importante es que el tropo no se vea como algo superfluo ni artificial, sino como la prolongación apropiada de la frase, la que ciñe el pensamiento a un lenguaje expresivo e imaginativo. $Y$ lo conciso y apretado de la relación se presta fácilmente al frecuente empleo de la imagen, la cual llega a constituir uno de los elementos constantes y de más efecto del poema. El hecho de que el lector aguarde el tropo y lo mire como parte esencial del poema significa que se ha amoldado al concepto estético que forma la base de la obra. Ni siquiera todas las imágenes són de primera calidad; algunas son francamente comunes y trilladas. No importa, pues el conjunto de imágenes es tan admirable que eclipsa a las débiles. Lo significativo para nosotros aquí es que la abundancia y la variedad de tropos en Martín Fierro es otro tecurso de que se sirve Hernández para mantener el alto nivel de interés en la obra.

Unas palabras u observaciones para concluir: En su nuevo volumen de ensayos, el distinguido crítico Lionel Trilling ${ }^{17}$ escribe largamente sobre la sinceridad en el arte literario. Aplicando esta afirmación a Martín Fierro, llegamos quizás a la clave de su gran interés: la candidez en la relación. Candidez en el lenguaje, en los móviles de acción, en los pensamientos, y sobre todo en la presentación de lo más íntimo y verdadero del gaucho. Y esta franqueza, esta sinceridad, concebida como uno de los ejes del criterio artístico, conduce al ininterrumpido interés de la obra. Con otra base estética - digamos la ironía, o la sátira, o la completa idealización del gaucho- no tendríamos el mismo Martín Fierro. Merced al genio de Hernández, existe en el poema una idónea articulación entre la materia narrada y la manera de presentárnosla. Y esto es tal vez su mayor gloria.

Myron I. LiChtBLAU

\section{Syracuse University}

16 Véase Eneida Sansone de Martínez, La imagen en la poesia gaucbesca (Montevideo: Universidad de la República, 1962).

${ }_{17}$ Lionel Trilling, Sincerity and Autbenticity (Cambridge, Mass.: Harvard University Press, 1972). 
